\title{
Cold Chain Logistics Development and Analysis of Necessity
}

\author{
Wei Wang \\ Beijing Wuzi University, Beijing, China \\ Email: wangwei199304@126.com
}

Received 26 May 2016; accepted 19 June 2016; published 22 June 2016

Copyright (C) 2016 by author and Scientific Research Publishing Inc.

This work is licensed under the Creative Commons Attribution International License (CC BY). http://creativecommons.org/licenses/by/4.0/

(c) (i) Open Access

\begin{abstract}
Agricultural and fishery products are during transport often require low temperature conditions of transport, in order to meet the basic performance of the product. Enterprises must change the product logistics and transport conditions for cold chain that can be applied to the field of logistics and ensure its quality. In this paper, logistics and transportation in Ningbo, for example, found that the highest close level Ningbo Economic development and agriculture; it is necessary to strengthen the control of agricultural cold chain logistics during transport, logistics and transport to ensure the quality of agricultural products, so that consumers get satisfaction products, and improve the reputation and service levels. From the enterprises themselves, we must introduce advanced technology and equipment, the introduction of outstanding intellectuals, strengthen the company's management and monitoring level, and improve the cold chain logistics and transport capacity, to provide support and protection for the economic development of enterprises.
\end{abstract}

\section{Keywords}

Management and Monitoring Level, Ningbo, The Cold Chain Logistics

\section{Introduction}

With the rapid development of advanced technologies, the level of China's economy has rapidly leaped, now ranked second in the world. Economic development of the country's power and carriage, economic development will inevitably bring other social sectors of industry, agriculture and enterprise development. It is often said that the economic base determines the superstructure, as long as there is a good economic foundation, the development of other industries will catch up the pace. In recent years, the development of the logistics industry on the subject of the economic level of support has been developed from the early to middle stage of development, but the process of development, there will still be many problems. The most important issue is the logistics distribu- 
tion process, logistics technology and logistics equipment relative to other countries, the level is very backward. In the process of logistics and transport, many agricultural and fishery products need well preserved, sometimes need cold chain, which requires a good refrigerated transport and cold chain transportation technology functions. For example, people are very familiar with the fruit, if in the case of summer heat, the room temperature in the logistics and transport will certainly be spoiled. We lost the taste and appearance of the original fruit. This requires that companies must follow the trend of the times, pay close attention to the technical aspects of the development of cold chain logistics, effectively guarantee the product during transport, the low-temperature control and regulation, logistics and transport products in the process of loss becomes small, before the product has not yet reached the consumer or retail outlets, can save as much as possible of the original high level of quality.

\section{Literature Review}

In recent years, the level of research and development of cold chain logistics has been greatly improved, many scholars put forward their views and opinions. Wu Qing Gang (2011) scholars present situation and development of cold chain logistics gives his point of view, and proposes to strengthen the cold chain logistics information on setting up the regulatory system through the network platform to enhance professional training mode [1]. Yang Shengping and Xie Jing (2013) two scholars from the actual fish octopus starting to study and explore the most appropriate temperature octopus, as well as in the most suitable temperature study how changes in the quality of the octopus by experiment [2]. Zhang Lin and Pang Yan (2011) for dairy products, this paper proposes the idea of joint distribution, and third-party logistics cooperation, establishment of cold chain logistics integration services [3]. Zhang Xiaoshuan and Xing Shaohua (2011) that the fish in the cold chain logistics and transport process must be monitored, and such monitoring on wireless network technology to combine, such as radio frequency identification technology, increase the intensity of supervision and management convenience [4]. Hu Tian Shi (2011) that the process of product cold chain transport, it is important to control the management point is that the level of the supply chain, supply chain level rise, will make cold chain transport technology has been improved and enhanced [5]. LORRAINE ice Qi Lin (2012) that the wireless sensor network technology to real-time monitoring system products, making it easy for enterprise product temperature and environment monitoring and timely adjustment of temperature, improve product environment [6].

\section{Necessity of Cold Chain Logistics}

The need for cold chain logistics enterprises and that people have to know, but for a place and a country, why should it accelerates the development of cold chain logistics business, which requires research and analysis of the product characteristics of the region, and products in the future development can be detailed and accurate forecasting, to identify the key issues in a timely manner to make a solution.

In this paper, we in Ningbo City, Ningbo Logistics is now increasingly high level of development of the logistics industry in Ningbo has always been many leaders and scholars fancy place. At the same time, Ningbo seafood and agricultural products is also very developed, high yield, praised by many. In order to work out the logistics and transport process in Ningbo City in the presence of the problem, we must find out the local logistics industry and which industry the highest correlation, then, this article from the Yearbook of logistics in Ningbo Ningbo agriculture, forestry, animal husbandry, GDP fisheries, services (in million) from 2000 to 2014 data from the lookup, because Ningbo port handling is a big country, the size of the port throughput reflects the level of the local logistics industry, port throughput is one important indicator of a direct impact on the rapid development of the local economy, so you can use the local gross production is approximately understood to GDP over the years of economic value, so that the GDP economic value as a reference level of the local logistics, the results shown in Table 1.

Through the use of mathematical and statistical software SPSS19.0 detailed analysis, the correlation between the extent of Table 2.

From the data we can analyze that X1 is the highest representative of agriculture, the local GDP and economic value associated with the degree of correlation reached 0.990, indicating that the development of agriculture in the local economy has a significant role in promoting, so you can explain, economic growth is inseparable from the development of agriculture. Agriculture logistics can not be ignored, the need for cold chain technology has improved. 
Table 1. Factors data analysis.

\begin{tabular}{|c|c|c|c|c|c|c|}
\hline Year & Agriculture & Livestock & Fisheries & Forestry & Services & GDP \\
\hline 2000 & 71.57 & 4.59 & 20.45 & 51.76 & 0 & 1144.57 \\
\hline 2001 & 74.31 & 5.14 & 22.21 & 54.77 & 0 & 1278.75 \\
\hline 2002 & 73.65 & 4.92 & 24.25 & 60.49 & 0 & 1453.34 \\
\hline 2003 & 77.42 & 5.03 & 26.03 & 63.10 & 2.17 & 1749.27 \\
\hline 2004 & 86.94 & 5.01 & 29.61 & 69.18 & 2.39 & 2109.45 \\
\hline 2005 & 91.14 & 5.31 & 32.93 & 75.31 & 2.71 & 2447.32 \\
\hline 2006 & 97.14 & 6.01 & 32.20 & 68.97 & 3.60 & 2874.42 \\
\hline 2007 & 107.22 & 6.77 & 46.27 & 72.67 & 4.02 & 3418.57 \\
\hline 2008 & 119.31 & 7.32 & 48.29 & 83.27 & 4.25 & 3946.52 \\
\hline 2009 & 134.64 & 8.85 & 47.87 & 90.82 & 4.60 & 4334.33 \\
\hline 2010 & 167.51 & 9.83 & 51.74 & 105.62 & 4.89 & 5181.00 \\
\hline 2011 & 191.64 & 10.86 & 62.54 & 127.68 & 5.21 & 6074.94 \\
\hline 2012 & 201.19 & 11.43 & 64.70 & 136.73 & 5.76 & 6601.21 \\
\hline 2013 & 202.28 & 11.64 & 60.54 & 148.29 & 5.96 & 7164.51 \\
\hline 2014 & 209.51 & 12.51 & 53.33 & 150.71 & 6.42 & 7610.28 \\
\hline
\end{tabular}

Table 2. Data correlation analysis.

\begin{tabular}{cccccccc}
\hline & GDP & X1 & X2 & X3 & X4 & X5 \\
\hline GDP: pearson correlation & 1.000 & 0.990 & 0.989 & 0.942 & 0.983 & 0.935 \\
Sig (2-tailed) & 0.000 & 0.000 & 0.000 & 0.000 & 0.000 & 0.000 \\
N & 15 & 15 & 15 & 15 & 15 & 15 \\
\hline
\end{tabular}

\section{Accelerate the Development of Cold Chain Logistics Recommendation}

After the above data analysis, we can conclude that the need for cold chain logistics development. In real life, as consumers living standards continue to improve, consumers also increased the requirements for high-quality goods, in order to meet the consumption needs of consumers, and so that they can speed development of the logistics industry today leading position in the enterprise, companies must accelerate their level of cold chain logistics, especially for logistics enterprises in the delivery of certain agricultural and fishery products such perishable and require cold chain products, accelerate the development of the more cold necessity of the logistics chain.

\subsection{Attract Outstanding Intellectuals}

Whether in business or company, if they wish to continue to have new ideas, research and development of new and innovative products, we can not rely on older employees excavation, with the level of knowledge and continuously updated alternately, many older employees knowledge already seem old-fashioned, which requires enterprises to continuously add fresh blood in the necessary time, in time to attract outstanding young intellectuals, educated youth intellectuals are now the new knowledge age, often with representatives and reliability. These young intellectuals into the company, will give businesses and companies advice and recommendations, and to give new ideas and practices for logistics companies, such talent is essential, they can be designed better cold chain technology and cold chain equipment, the personnel of the research and development of these small teams, the rear support the company's R \& D technology to provide a reliable guarantee for the company's logistics development.

\subsection{Establishment of Expert Scoring Team}

Enterprises often have development process, the process of enterprise development must be evaluated and re- 
viewed. Logistics enterprises in the transport of the product, will certainly be a lot of problems for a transport of agricultural products logistics companies, quarterly and annual losses are immeasurable. However, companies can set up expert scoring team within the company, the role of these groups are as follows. First, they can every quarter or every year transport products detailed statistics, such as the purpose is to find the cause of the problem, you can find out the logistics and transport during the quarter in which the goods which are more easily damaged, then the business special care should be considered in the quarter of the product during transport temperature control and other factors adjusted. Secondly, expert scoring team can establish a standard based on the survey results, all in the logistics and transport process, it is possible that the amount of product loss below the target of the establishment, you can give employees incentives, so that you can motivate employees to transport goods to protect and control low-temperature process. Of course, the amount of loss we must ask when the index is higher than the cause, if it is because of their own technical reasons, it must be improved, if the employee is in the process of working no cold chain products, resulting in losses on We have responsibility to the people, has the responsibility of employees need to be punished. Finally, such a process the company management team also played a role in protection.

\subsection{Introduction of Advanced Technology and Cold Chain Equipment}

No matter how human control and operation, ultimately comes down to the reason or enterprise technology and equipment. An enterprise technology and equipment is very backward, even if the employee then outstanding, to no avail. Therefore, in order to ensure that products maintain a good color appearance and taste in the logistics and transport, it is necessary to improve the cold chain enterprise technology and equipment. First, companies should learn from the advanced experience of outstanding business, to study the appropriate technical knowledge to ensure that in the field of knowledge does not fall behind. Second, companies should attract professional and technical personnel, and the purchase of advanced cold chain logistics transportation equipment, complete use of learning technology and cold chain equipment under the guidance of technicians. The most important is the effective use of the cold chain equipment to transport logistics, transport vehicles in the library, it is possible at any time to adjust the temperature, so that the temperature inside the garage stored products meet the conditions, and is capable of real-time monitoring, if there are problems in time react and adjust. After the introduction and use of technology and cold chain cold chain equipment, logistics and transport companies in a process similar to agricultural products, the loss can effectively guarantee product performance, reduce product waste, transport logistics services to enable enterprises to be raised.

\section{Conclusion}

Logistics and transport enterprises are in the process that the performance and characteristics of the product are difficult to effectively preserve. Enterprises must set up a good supervision system and the cold chain transportation equipment. Professionals need to assess regulatory system. First of all, the enterprises should control the years of systematic analysis of the product transportation data; the staff draws a standard or line based on these values. Employee's work efficiency higher or lower that line has a corresponding standards and guidelines for the management. In addition, cold-chain transportation equipment is a necessary factor in the introduction of advanced cold-chain equipment business, the need for systematic study and practice, so that the cold chain equipment to play a good role in the transport process. Combination of management and technology will bring the cold chain logistics and transport companies to achieve high efficiency.

\section{References}

[1] Yang, S.P., Xie, J., Gao, L., Qian, Y. and Fang, S.J. (2013) Bing Cold Chain Logistics Process Temperature and Time of Chilled Octopus Quality. Journal of Agricultural Engineering, 24, 302-310.

[2] Wu, Q.G. (2011) Present Situation of Cold Chain Logistics Development and Countermeasures. Chinese Economic Circulation, 2, 24-28.

[3] Zhang X.S., Xing, S.H. and Fu, Z.T. (2011) Tiandong Aquatic Cold Chain Logistics Technology Status, Trends and Countermeasures. Fisheries Modernization, 3, 45-49.

[4] Zhang, L., Pang, Y. and Xia, J. (2011) Xue Dairy Companies Cold-Chain Logistics and Distribution Joint Research. Enterprise Economy, 12, 89-92.

[5] Qi, L., Han, B., Zhang, X.S., Xing, S.H. and Fu, Z.T. (2012) WSN-Based Real-Time Monitoring of Aquatic Products 
Cold Chain Logistics System. Agricultural Machinery, 8, 134-140.

[6] Hu, T.S. (2010) Cold Chain Logistics Development. Beijing Technology and Business University (Social Science Edition), 4, 12-17.

\section{Submit or recommend next manuscript to SCIRP and we will provide best service for you:}

Accepting pre-submission inquiries through Email, Facebook, Linkedin, Twitter, etc

A wide selection of journals (inclusive of 9 subjects, more than 200 journals)

Providing a 24-hour high-quality service

User-friendly online submission system

Fair and swift peer-review system

Efficient typesetting and proofreading procedure

Display of the result of downloads and visits, as well as the number of cited articles

Maximum dissemination of your research work

Submit your manuscript at: http://papersubmission.scirp.org/ 